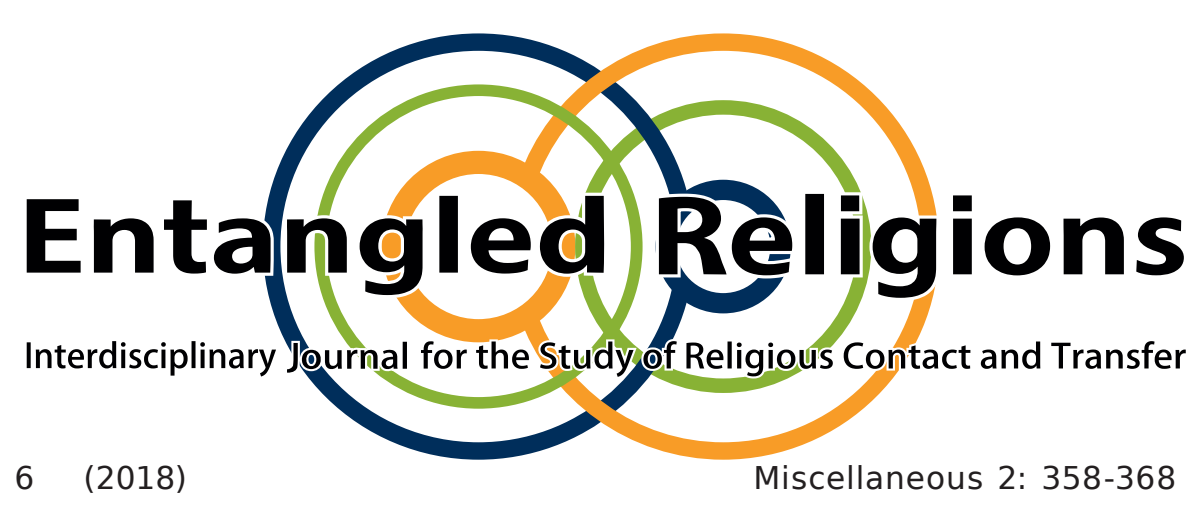

\title{
Mapping Jewish-Christian Relations from the Mediterranean to the Indian Ocean (600-1800)
}

An Introduction to JCR-MIO

BARBARA ROGGEMA

JewsEast, Center for Religious Studies, Ruhr-Universität Bochum, Germany

\section{License: (C)}

This contribution to Entangled Religions is published under the Creative Commons Attribution-NonCommercial-NoDerivatives 4.0 International Public License (CC BY-NC-ND 4.0 International). The license can be accessed at http://creativecommons.org/licenses/ by-nc-nd/4.0/ or is available from Creative Commons, 559 Nathan Abbot Way, Stanford, California 94305, USA

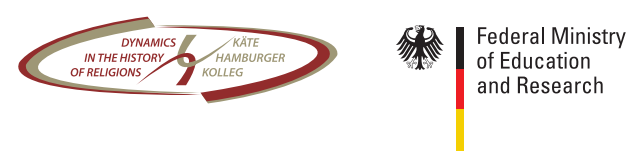




\title{
Mapping Jewish-Christian Relations from the Mediterranean to the Indian Ocean (600-1800)
}

\author{
An Introduction to JCR-MIO
}

BARBARA ROGGEMA

Ruhr-Universität Bochum, Germany

\begin{abstract}
This brief article describes how the research team of the ERC-project JewsEast is preparing a major inventory of sources from the Mediterranean to the Indian Ocean that address Jewish-Christian relations in these regions. In it is explained what types of source material will be treated in the survey.
\end{abstract}

KEY WORDS Jewish-Christian relations; Middle East; Caucasus; Ethiopia; Indian Ocean

Although Jewish-Christian relations form a heavily researched topic, studies of these relations have been, by and large, restricted to the areas in which Jews were living in societies dominated by Christianity, mostly around Europe and in Byzantium. One can think of obvious reasons why this is so. Apart from the fact that, in general, the West is a more likely area for research to be chosen by scholars than other parts of the world, the historiography of Jewish-Christian interaction has centred on the uneven balance of power between Christians and Jews in a world where Christianity was dominant and Jews were a minority. Beyond that world of Christian Europe lies a vast geographic area, from the east of the Mediterranean to the Indian Ocean, where indigenous Christians and Jews have also interacted since Late Antiquity. The study of relationships between these 
communities on a local level and their mutual image-making is still in its infancy.

A large research project, funded by the European Research Council and based at the Ruhr-Universität Bochum in Germany, intends to counterbalance the study of Jewish-Christian relations by looking at societies beyond Europe, where these relations have hardly been researched and where the social dynamics between the two communities can be expected to have been different. A five-year project, Jews and Christians in the East: Strategies of Interaction between the Mediterranean and the Indian Ocean (in short: JewsEast), headed by Prof. Alexandra Cuffel under the auspices of the European Research Council (ERC), endeavours to study JewishChristian interaction in the Arab world, the Caucasus, Ethiopia, and South India during the period 600-1800.

\section{The Source Survey JCR-MIO}

One of the major outcomes of the JewsEast project will be a survey of the relevant sources for Jewish-Christian interaction in these areas. The threevolume source survey will appear under the title Jewish-Christian Relations from the Mediterranean to the Indian Ocean (600-1800) at Arc Humanities Press, in print and as an online resource. The researchers involved in JewsEast, whose collective expertise covers the geographical areas and the respective languages, are taking stock of the sources which should be discussed in the volumes. Relevant sources are those that describe and/ or construct the relations between Jews and Christians, either between the communities and religions as a whole or as reflected in contacts between individual members of these religions. The amount of sources to be included is vast and covers a wide variety of genres: historiography, 
letters, biblical exegesis, apocalypses, refutations, travelogues, theological handbooks, hagiography, inscriptions, and so on. A large share consists of normative writings, whose authors' primary aim was to create clear boundaries between the two religions: refutations, polemical legends, and apologetics. In the Arab world, in particular, Christians wrote many texts of the Adversus Judaeos genre, but they are also to be found among the Armenians, Georgians, and Ethiopians. Another genre aimed at creating boundaries is legal literature. There are a considerable number of legal sources in which norms are set about intermarriage, conversion, and daily encounters.

In contrast to these are numerous writings which are not based on preconceived constructs about Jewish-Christian difference, for example certain chronicles and letters. They are descriptive or documentary in character and capture a world where, at times, the boundaries between the religions were more fluid, for example when we read of a Jewish teacher in Baghdad sending his visiting student to the Patriarch to discuss an exegetical point (Dubovick 2018) or a Coptic Christian visiting a Jewish scholar to ask about the exact quantity of oil needed for the preparation of the chrism (Villecourt 1928). The Cairo Geniza is of crucial importance in this respect. It provides us with texts which reflect the social and economic interactions between the communities (Cuffel, forthcoming). Each document which sheds light on intercommunal interactions will be discussed individually in JCR-MIO. These interactions are not only masked by the more formal and prescriptive texts, but also because the bulk of writings of each community is predominantly focused on internal dynamics. This aspect of the source material represents a practical challenge for the JCR-MIO project: the search for depictions of and reflections on JewishChristian interaction in the broader, non-confrontational, literary output over these hundreds of years evokes the proverbial needle in the haystack. 
Nevertheless, the JewsEast research team has taken on this challenging task, which forms one of the pillars of the envisaged source survey.

In addition to written sources, parts of the volumes will be devoted to material culture. One can think here of depictions of Jews found in Armenian manuscripts, the Kollam Copper plates' inscription reflecting Jewish and Christian encounter in South India, and archeological finds which shed light on the interaction between Christians and the Beta Israel in Ethiopia (see, for example, Kribus and Krebs 2018).

\section{Writings by Outsiders}

There is yet another relevant category of writings: those written by outsiders, that is to say, by authors who are neither Eastern Christian nor Jewish. One important genre here is travelogues, written, for example, by European pilgrims to Jerusalem and Muslim travelers touring the world of Islam. Such texts do not focus on Jewish-Christian relations per se, but they may shed sidelight on these through observations and anecdotal descriptions of events. For instance, the seventh-century abbot of Iona, Adomnán, related the pilgrimage of a bishop called Arculf to Jerusalem in his De Locis Sanctis. Although much of the narrative may not reflect an eyewitness account of the seventh-century Near East, Hoyland and Waidler have argued that despite its miraculous elements, a passage about 'believing Jews' (converts to Christianity or Judeo-Christians) and 'unbelieving Jews' appealing to the Caliph Mu'āwiya during a dispute about a cloth from Christ's sepulcher might well reflect a historical controversy (2014).

Among the works by outsiders are also works of Islamic law which deal partially or wholly with dhimmīs. The Muslim authors mostly saw them 
as one category and did not differentiate between them or regulate their mutual relations. There are exceptions, however. For example, the Hanbalī jurist Abū Bakr al-Khallāl (d. 923) deals with the question of interreligious encounters between dhimmīs (Prejean, forthcoming).

\section{The Quest for Sources}

In the ongoing quest for relevant sources, the JewsEast team benefits from a number of classic survey works, such as Steinschneider's Polemische und apologetische Literatur in arabischer Sprache zwischen Muslimen, Christen und Juden (Leipzig 1877) and Graf's Geschichte der christlichen arabischen Literatur (5 vols, Città del Vaticano, 1944-1953), as well as more recent studies, such as Rosenkranz's Die jüdisch-christliche Auseinandersetzung unter islamischer Herrschaft. 7.-10. Jahrhundert (Bern 2004). However, from the beginning of the project, it has become clear that the works featured in these studies are only the tip of the iceberg. Numerous unknown or unstudied texts are coming to light through two different channels. First of all, there are a number of ongoing digitization and cataloguing projects. Major libraries such as the Vatican Library, the National Library of France, and the British Library are digitizing their manuscripts as we speak. The cataloguing and digitizing efforts of the Hill Museum and Manuscript Library at St John's University, Minnesota, have opened up an immense world of major and minor manuscript collections. For Ethiopia, the project of EthioSpare at the University of Hamburg is an asset. For the exploration of the Cairo Geniza, we benefit from the 'Friedberg Genizah Project' of the Friedberg Jewish Manuscript Society and the Cambridge Digital Library.

A second avenue leading to the discovery of many more relevant sources is through the rereading of known texts which have not been read 
before with an eye to studying Jewish-Christian interaction. A prominent example is the genre of Christian Arabic apologetics. Works of this genre have been read by scholars as windows on early Muslim-Christian relations in the Middle East. Indeed, many of them appear to have been written in response to Islamic domination and polemic. Yet, numerous of these texts pay ample attention to Jews and aim to prescribe attitudes to Judaism by explaining how Jews fail to recognize the Christian view of the "Divine plan". Hagiographies often incorporate attitudes towards Judaism, too, but may not have been read through that lens before. The same counts for exegetical works. Anti-Christian tendencies in Jewish exegesis have been noticed by modern scholars, yet only a systematic rereading of the relevant texts will lay bare to what extent the exegetes aimed at conveying their views on Christianity in their works.

\section{Describing the Source Material}

Each and every individual work will be treated separately in JCR-MIO, but obviously there will be more to say about a source devoting ample attention to the Other or even having the other religion its primary target than a source which contains the occasional comment about interreligious encounters. Works which fall into that first category will be dealt with in more elaborate entries, which give a brief introduction to its author, a detailed description of the contents, themes, and reception of the work of up to 700 words, and its full bibliography, including references to manuscripts if the text is unedited. In cases where the text was translated into another language, the reception in the new language will be discussed as well. Transmission from one Eastern Christian language to another was quite common and hence we see works such as the Syriac Life of 'Abd al- 
Masīh in later versions in Arabic, Armenian, and Georgian (Butts and Gross 2016). Bringing together the various versions of such travelling tales will help to map out the routes along which texts-and, therefore, ideastravelled. These longer entries will be arranged chronologically and cover a significant part of the three volumes.

Sources which deal only partially with the other religion, for example midrash, liturgical texts, or the numerous Christian refutations of Islam in which Jews play a subsidiary role, will be grouped according to genre and feature in entries, which are shorter but nevertheless highlight the main themes and the relevant scholarly literature.

\section{Limits}

The research team is casting a wide net in its search for relevant sources and in its aim to be as comprehensive as possible, and will include some texts which, upon closer consideration, may only seem of marginal importance for the study of eastern Jewish-Christian relations. There is the pitfall of over-inclusion. We can think of hundreds of Christian texts in which there are trivial references to Jesus' Jewish origins. They will not be deemed relevant. Decision-making about texts of borderline relevance requires much reflection and discussion. A rule of thumb has nevertheless been established: if texts revolve only around one's own community and feature the other community only as part of that discussion because of prior and known adoption of notions of that latter community into the former, then the text does not express a fact or idea about Jewish-Christian relations (historical, contemporary, or idealized). Therefore, the text will not be included. A good example is a recently translated law book, written by a seventh-century East-Syrian scholar, which contains an introduction 
to the evolution of Christian law (Harrak 2017). The author explains that Christian law is partly derived from Mosaic law but that not all of Mosaic law is relevant for Christians. He gives some examples to show that some of the Mosaic laws were intended only for the Jewish people and he points out that even for them, over time, practice diverged from scriptural norms. The remark that Jewish law has evolved over time is a very general one and, for the rest his reflection on Mosaic law, is only part of the jurist's sketch of the origins of canon law. Its significance does not seem to go beyond that. This is why the text will not be dealt with in JCR-MIO.

\section{Limitations}

For the Middle Eastern part of the project, there is a wealth of sources to consider. For other regions, such as the Caucasus and South India, the source material is scarcer. This means that the source survey may not accurately reflect the quantity or quality of contact between Jews and Christians in these areas over history. However, the source survey is meant precisely for unearthing more sources and ones of better quality for those regions that are currently left outside of scholarly attention.

\section{Outcome}

The volumes are expected to appear between 2019 and 2021. They will be a significant step in the study of global Jewish-Christian relations. Hopefully, they will lay the foundation for the study of Jewish-Christian relations in the Eastern hemisphere as a new field of research. 


\section{Research team}

$\begin{array}{ll}\begin{array}{l}\text { Armenia } \\ \text { Zara Pogossian } \\ \text { Georgia } \\ \text { Stephen Rapp }\end{array} & \begin{array}{l}\text { India } \\ \text { Ophira Gamliel } \\ \text { Istvàn Perczel } \\ \text { Radu Mustata }\end{array} \\ \text { Ethiopia } & \text { Arab world } \\ \text { Sophia Dege-Müller } & \text { Alexandra Cuffel } \\ \text { Bar Kribus } & \text { Barbara Roggema }\end{array}$

\section{Reference List}

Butts, Aaron M., and Simcha Gross. 2016. The History of the 'Slave of Christ'. From Jewish Child to Christian Martyr. Piscataway: Gorgias Press.

Cuffel, Alexandra. Forthcoming. “From 'Convivencia' to Competition: Conversion and Religious Polemic between Jews and Christians focusing on Egypt from Fatimid-Mamluk periods." In Minorities in Contact, edited by Clara Almagro Vidal, Jessica Tearney-Pearce, and Luke Yarbrough. Turnhout: Brepols.

Dubovick, Yosaif Mordechai. 2018. "'Oil, which shall not quit my head': Jewish-Christian Interaction in Eleventh-Century Baghdad." Entangled Religions 6: 95-123.

Harrak, Amir. 2017. "The Law Code of Simeon, Bisop of Rev-Ardashir: Presentation and Translation." Journal of the Canadian Society of Syriac Studies 17: 49-68. 
Hoyland, Robert G., and Sarah Waidler. 2014. “Adomnán's De Locis Sanctis and the Seventh-Century Near East." English Historical Review 129 (539): 787-807.

Kribus, Bar, and Verena Krebs. 2018. “Beta Israel (Ethiopian Jewish) Monastic Sites North of Lake Tana: Preliminary Results of an Exploratory Field Trip to Ethiopia in December 2015." Entangled Religions 6: 309-344.

Prejean, Chris. Forthcoming. "Abū Bakr al-Khallāl, Aḥkām Ahl alDhimma." Routledge Medieval Encyclopedia. Abingdon: Taylor $\&$ Francis.

Villecourt, L. 1928. "Le livre du chrême (Ms. Paris arabe 100)." Le Muséon 41: 49-80. 